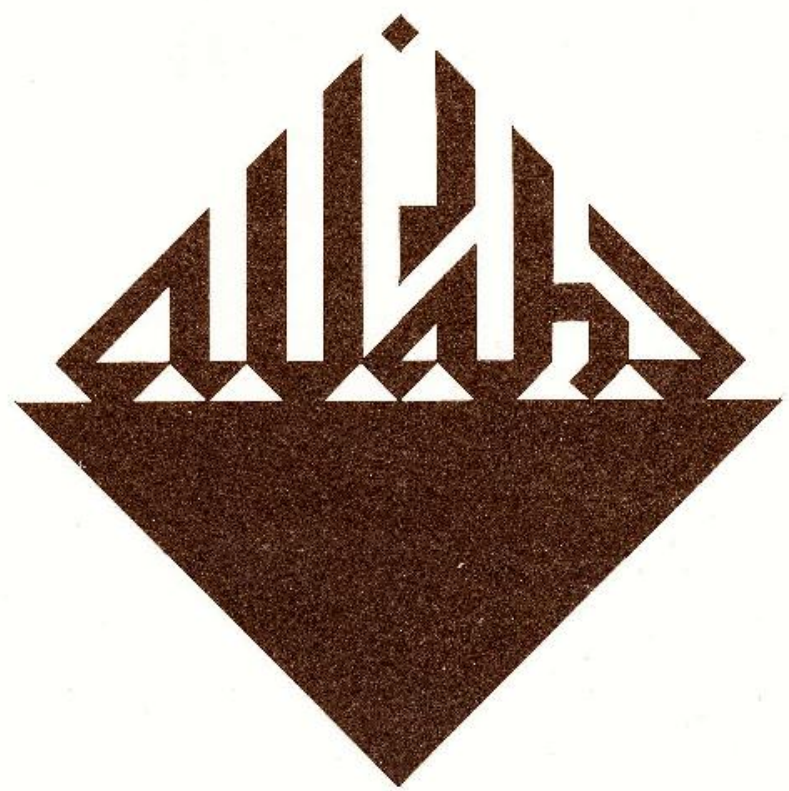

ISLAM AND DEMOCRACY:

IN SEARCH OF A VIABLE SYNTHESIS

Bahtiar Effendy

MODERNITY AND THE CHALLENGE OF PLURALISM:

SOME INDONESIAN LESSONS Robert W. Hefner

ISLAMIC POLITICAL THOUGHT AND CULTURAL REVIVAL IN MODERN INDONESIA M. Din Syamsuddin

WESTERN STUDIES OF SOUTHEAST ASIAN ISLAM:

PROBLEM OF THEORY AND PRACTICE John R. Bowen 


\title{
STILDLA ISLAMIKA
}

Indonesian Journal for Islamic Studies

Volume 2, Number 3, 1995

\author{
EDITORLAL BOARD: \\ Harun Nasution \\ Mastubu \\ M. Quraish Sbibab \\ A. Aziz Dablan \\ M. Satria Effendi \\ Nabilab Lubis \\ M. Yunan Yusuf \\ Komaruddin Hidayat \\ M. Din Syamsuddin \\ Muslim Nasution \\ Wabib Mutbi \\ EDITOR-IN-CHIEF: \\ Azyumardi Azra \\ EDITORS: \\ Saiful Muzani \\ Hendro Prasetyo \\ Joban H. Meuleman \\ Nurul Fajri \\ Badri Yatim \\ ASSISTANTS TO THE EDITOR: \\ Arief Subban \\ Heni Nuroni \\ ENGLISH LANGUAGE ADVISOR: \\ Juditb M. Dent \\ ARABIC LANGLAGE ADVISOR: \\ Fuad M. Facbruddin \\ COVER DESIGNER: \\ S. Prinka
}

STUDLA ISLAMIKA (ISSN 0215-0492) is a journal published quarterly by the Institut Agama Islam Negeri (IAIN, The State Institute for Islamic Studies) Syarif Hidayatullah, Jakarta. (STT DEPPEN No. 129/SK/DITJEN/PPG/STT/1976) and sponsored by the Department of Religious Affairs of the Republic of Indonesia. It specializes in Indonesian Islamic studies, and is intended to communicate original researches and current issues on the subject. This journal warmly welcomes contributions from scholars of related disciplines.

All articles published do not necessarily represent the views of the journal, or other institutions to which it is affiliated. They are solely the views the authors. 


\title{
M. Din Syamsuddin
}

\section{Islamic Political Thought and Cultural Revival in Modern Indonesia}

\begin{abstract}
Abstraksi: Dilibat dari pemikiran politik Islam, sedikitnya ada tiga arus pemikiran di kalangan intelektual Islam Indonesia: arus formalistik, arus substantivistik, dan arus fundamentalistik.

Arus formalistik menekankan penggunaan bentuk-bentuk Islam yang diikuti secara ketat. Ia menekankan simbol-simbol budaya Arab yang dipercaya sebagai Islam yang murni. Menekankan penggunaan termaterma budaya Arab di negara non-Arab seperti Indonesia, menunjukkan pentingnya bagi mereka formalisme keagamaan. Makna-makna substantif yang bisa diungkapkan dengan bahasa lain dipandang kurang penting dibanding kalau diungkapkan dalam bahasa Arab. Tekanannya di sini terletak pada pengaruh nyata dari kata-kata dari pada makna epistemologis dari pemahaman.
\end{abstract}

Beberapa unsur dari kecenderungan formalistik ini ada pada kelompok intelektual universalis. Menurut kelompok ini Islam adalab agama universal dan menyelurub (total). Ia menekankan kekuasaan Tuhan di bumi, dan, seperti pandangan fundamentalisme Islam, babaya "Westoxication" atau "masyarakat jabili modern". Bagi kelompok universalis, Islam harus dilembagakan agar menjadi kekuatan bagi pembebasan di dunia ini. Pelembagaan ini akan membuka jalan bagi terbentuknya masyarakat modern Qur'anis. Pelembagaan Islam ini merupakan ciri utama dari kecenderungan formalisme Islam.

Dalam wilayah politik, arus formalisme Islam memandang mendesaknya suatu bentuk institusi politik Islam (negara atau partai politik Islam). Arus formalisme Islam bertentangan dengan arus Islam substantivistik. Yang terakbir ini menekankan substansi dari pada bentuk, nilainilai Islami dari pada lembaga-lembaga formal yang berlabel Islam. Perhatian utama kelompok ini adalah bagaimana nilai-nilai Islami bidup dan berpengaruh dalam lembaga-lembaga politik tanpa harus memberikan label Islam terbadap lembaga-lembaga tersebut. Langkab yang ditempuh kemudian lebih pada kultur dalam rangka membangun Indonesia moderen. 
Gagasan pendekatan kultural dari pada pendekatan politik dalam Islamisasi Indonesia membuka ruang bagi mungkinnya pribumisasi Islam, yakni mewujudkan nilai-nilai universal Islam ke dalam kultur bang. sa Indonesia yang beragam. Dalam konteks ini pula kultur Islam barus dipandang hanya sebagai salah satu dari sekian banyak kultur bangsa. Ia hanya bersifat komplementer terbadap kultur Indonesia secara keselurub. an. Dengan pemikiran ini diharapkan masyarakat Muslim punya kesadaran kebangsaan, dan negara Indonesia barus dibangun atas dasar kesadaran ini.

Gagasan substantivistik berimplikasi pada perlunya deideologisasi Is. lam. Dengan kerangka ini, posisi Islam menjadi jelas dan absab dalam menerima Pancasila sebagai ideologi negara Indonesia.

Islam substantivistik ini juga menjelma dalam komitmen lain atas bangsa dan masyarakat Indonesia. Ia tidak hanya bergerak pada level intelektual dan tersosialisasi secara kultural, melainkan pada gerakangerakan sosial dan ekonomi pada tingkat masyarakat. Ini mengambil bentuk dalam gerakan-gerakan NGO. Gerakan ini pada dasarnya tidak politis, namun dapat berdampak politik. Karena ia punya perbatian besar terhadap pemberdayaan masyarakat lapisan bawah yang pada gilirannya diharapkan dapat membangun masyarakat sipil yang kuat.

Di samping dua arus di atas, arus Islam fundamentalis dan revivalis dalam pemikiran politik Islam juga perlu mendapat perhatian. Arus ketiga ini memandang babwa dua arus di atas telah gagal membuktikan Islam sebagai kekuatan tanding (counter) atas modernisasi Indonesia. la menekankan agar dasar-dasar Islam masuk ke dalam realitas sosialpolitik Indonesia, dan berupaya untuk menghidupkan kembali kultur Islam. Arus ini juga berusaha untuk bereksperimen dengan apa yang mereka anggap sebagai lembaga-lembaga Islam. Mereka berupaya menjadikan gerakan mereka sebagai oposisi atas Islam yang mapan.

Gerakan-gerakan fundamentalis ini terus meningkat, namun diperkirakan tidak akan berkembang menjadi kekuatan yang signifikan secara politis di Indonesia. Ia muncul dari situasi politik tertentu ketika masyarakat Muslim terancam, dan tidak ada organisasi Islam yang bersuara. Maka ketika organisasi-organisasi Islam menjadi lebib artikulatif, gerakan fundamentalis akan menjadi tidak signifikan lagi.

Di samping itu, gerakan fundamentalis Islam juga tidak menarik bagi bagian terbesar masyarakat Indonesia. Karena watak masyarakat Islam Indonesia pada dasarnya toleran dan moderat, dan karena itu tidak mudah menerima alternatif-alternatifradikal bagi perubaban seperti yang sering diperjuangkan kelompok fundamentalis Islam. Kecenderungan politik Indonesia sekarang yang lebih kondusif bagi Islam juga dapat meng. bambat berkembangnya gerakan ini. 


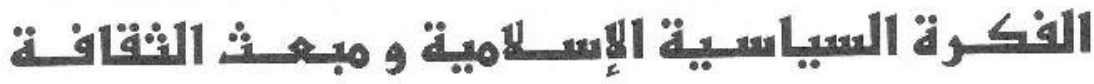 الإسلامية في إندونيسيسيا}

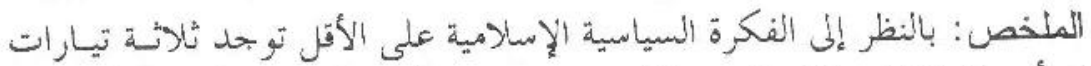

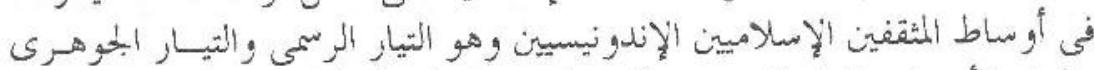

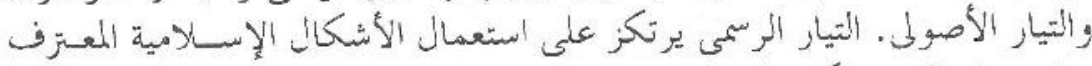

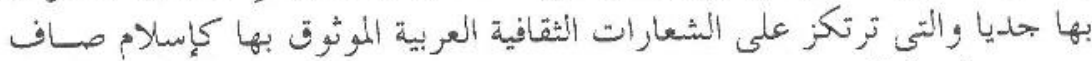

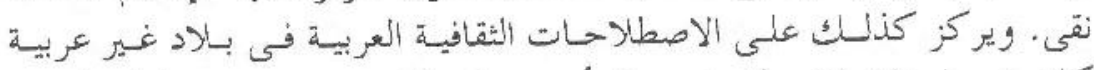

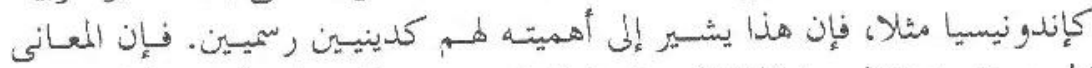

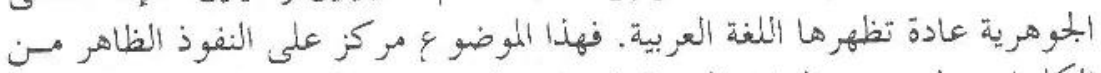

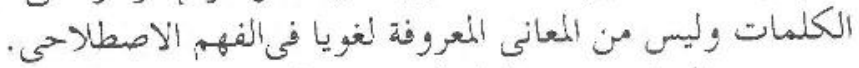

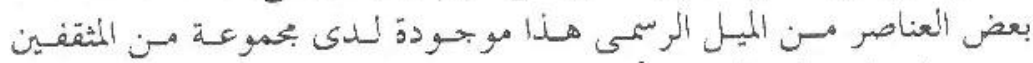

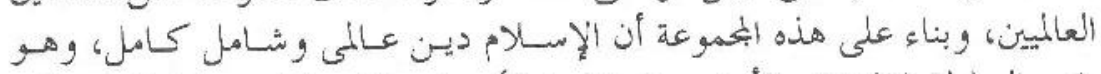

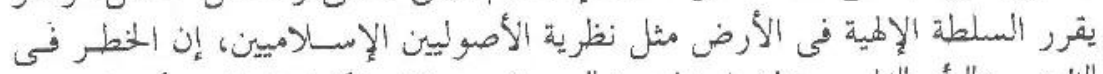

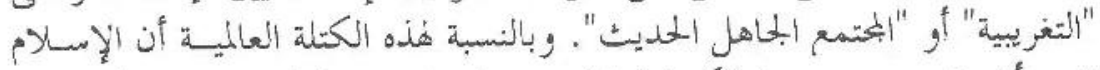

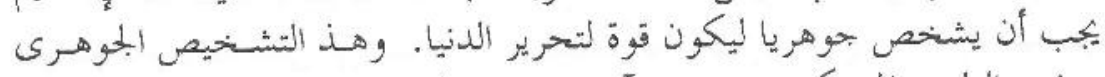

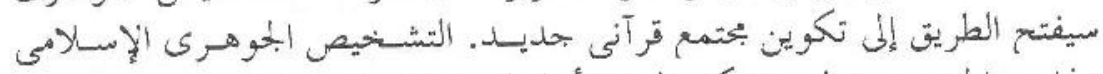

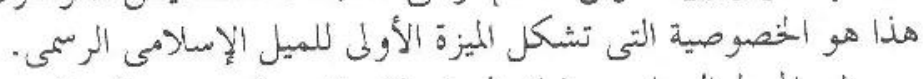

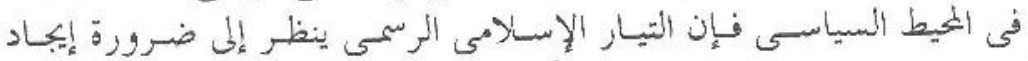

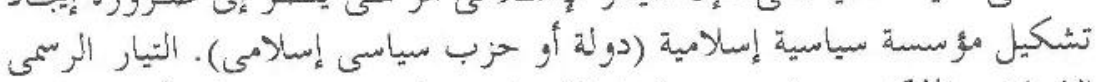

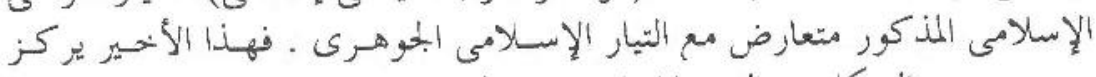

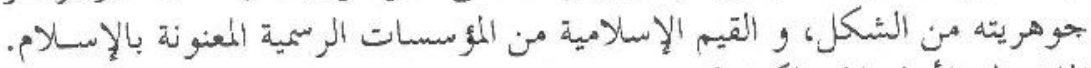

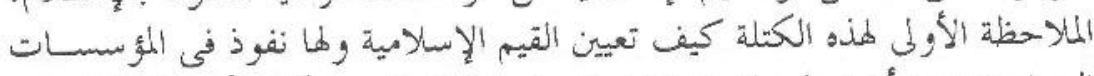

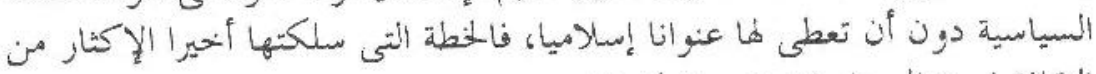
الثقافة فى بحال بناء إندونيسيا الحلديثة. 


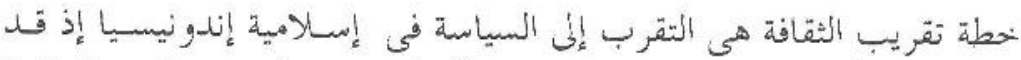

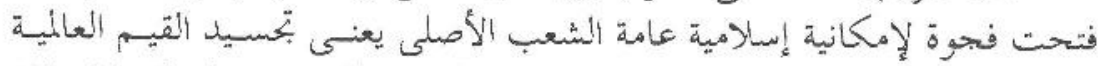

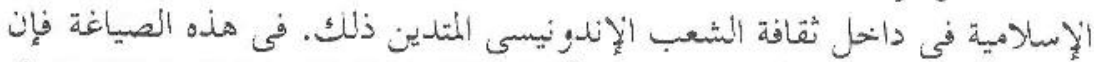

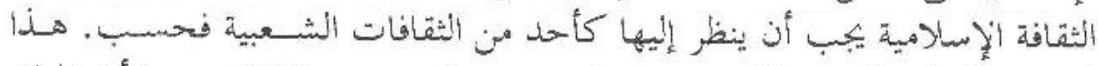

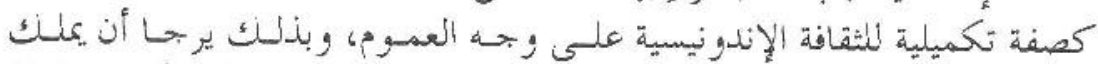

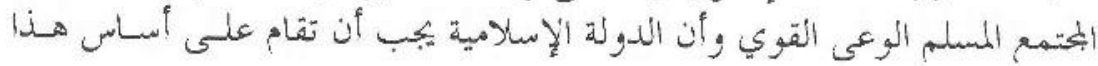

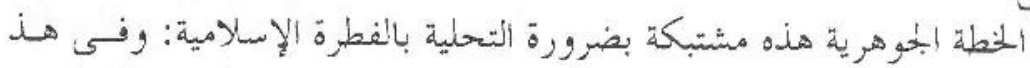

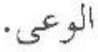

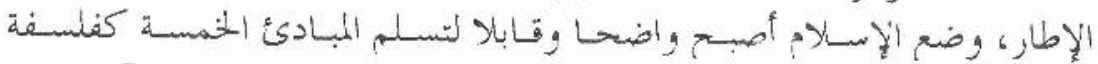

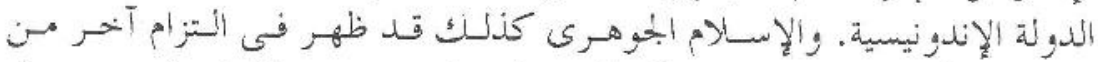

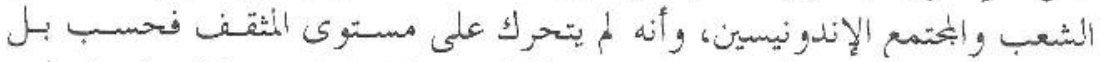

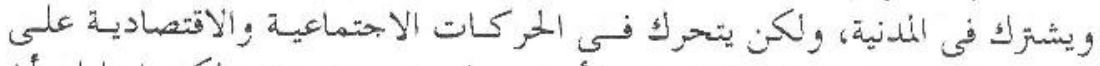

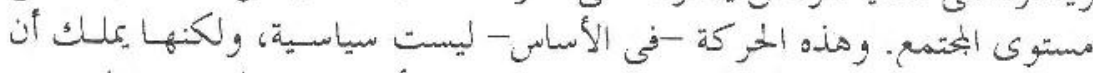

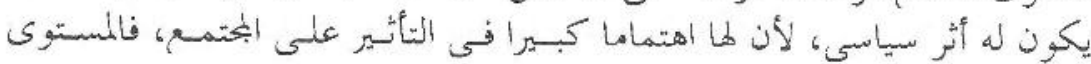

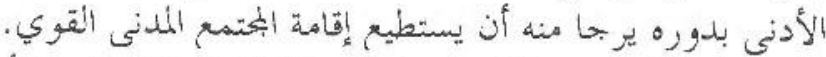

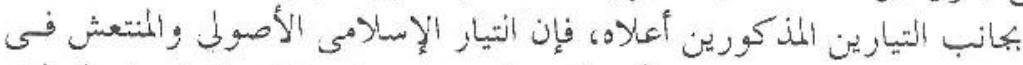

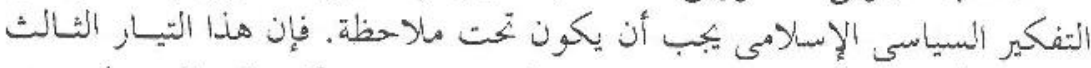

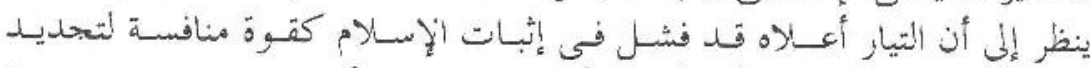

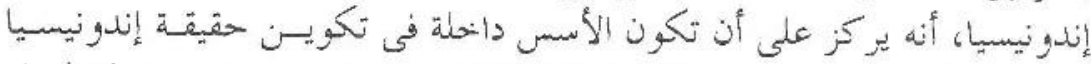

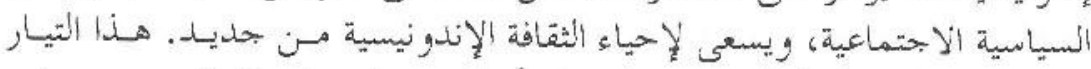

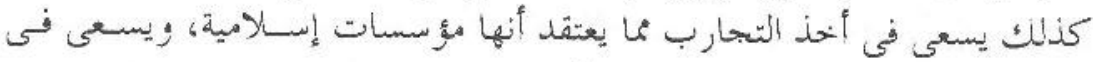

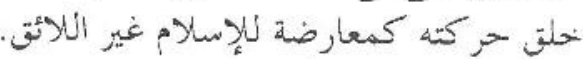

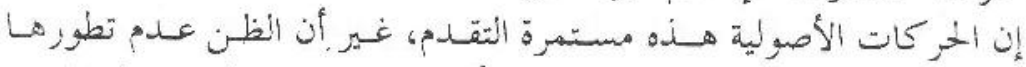

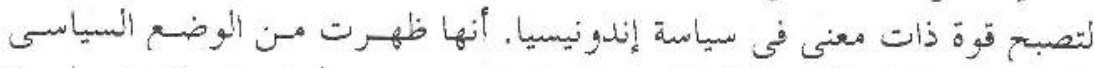

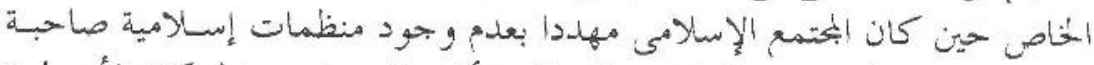

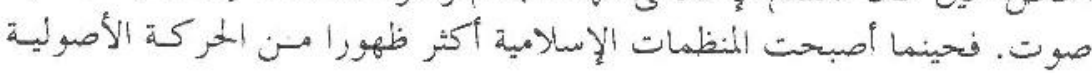

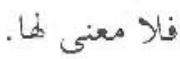

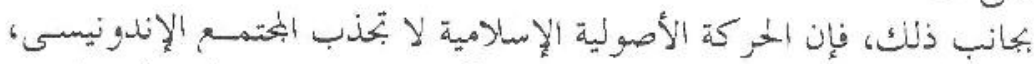

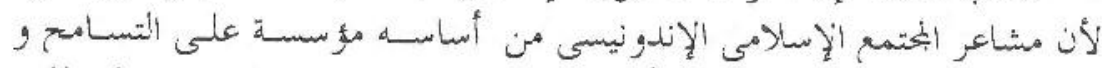

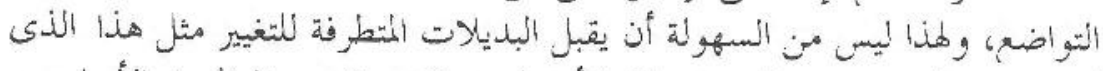

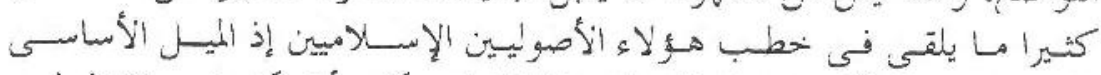

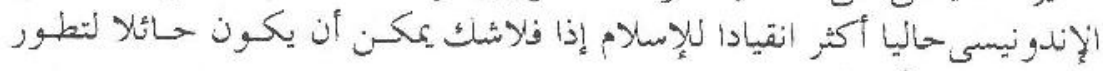
هذه الخحر كة ألأصولية. 
his paper tries to describe the dynamic of Islamic political thought in modern Indonesia (particularly during the New Or1 der period). It argues that during this period a significant number of Muslim intellectuals have developed ideas which serve as an intellectual response to the modernization of Indonesia. Islamic political thought has played an important role in this context. It became one of the determinant variables for the transformational practices of Islamic polity which, in turn, encouraged a harmonious relationship between Islam and the state. This, together with internal dynamics of the Muslim community, has paved the way for a cultural revival of Islam.

The paper does not pretend to render a value judgment either about the level of sincerity in the relationship, nor about the degree of that cultural revival. The ensuing discussion is an attempt to illustrate the variety of ideas among Muslim intellectuals regarding the appropriate political relationship between Islam and the state, upon which remarks about the cultural revival of Islam are rendered. In so doing, this paper touches upon some dimensions of modern Islamic political thought in Indonesia, which includes its historical roots and socio-political setting, mainstreams, and contributive role towards an Islamic cultural revival.

The emergence of political ideas among Muslim intellectuals in the face of the regime's modernization project and political agenda is perceived as part of the defense mechanism by supporters of political Islam, who seem to be passing the phase of self-resignation and projection toward a cultural retrospection. ${ }^{1}$

\section{Islamic Political Thought: An overview}

Islamic political thought reflects a long-standing and continuing intellectual inquiry into the nature and role of government as an indispensable instrument to secure both religious and temporal affairs, and to implement Islamic ideals within society. This is the result of serious efforts in exploring Islamic injunctions (ijtihâd) and domesticating them into a particular real politik in any given time. In this context, political thought includes both power politics to provide theories about the system of government and allocative politics as a way of implementing Islamic values into the political process. ${ }^{2}$

As with other aspects of Islamic thought, Islamic political thought deals with two conceptual problems: the problem of the relationship between revelation and reason, and that of the relationship be- 
tween religion and culture. Islamic political theorizing is thus an effort to reconcile the demands of the sharía $a b$ and political realities.

The reconciliation process has, in the course of time, produced a variety of tendencies and mainstreams, that primarily stemmed from the absence of any clear cut explanations of the issue in the very sources of Islam, the Qur'ân and the Sunnah, and how the two were interpreted by various Muslim political thinkers. Diverse socio-political and cultural conditions also influenced the nature of ideas and their expression.

Since Muslim political thinkers have as their point of departure the same religious belief (i.e., Islam) and have a common concern, namely about how to realize Islamic injunctions into political realities, these thinkers posited the shari' $a b$ as the ethical and moral basis for political expediencies. Yet their perception of the shari'ah and how it should be implemented in the political sphere reveal a diversity of ideas, as shown by the existence of various tendencies and paradigms.

These paradigms, although they maintain a symbiosis between religion and politics in Islam, each has a different emphasis. The premodern (Sunni) paradigm emphasized the supremacy of religion over politics and offered legitimating theories - based either on Islamic legal ideas, and pre-Islamic practices and moral teachings, or on speculative and idealized concepts of the existing political milieu. These theories of legitimacy served to confirm the existing political institution, i.e., the historic caliphate, without critical inquiry into the validity of its nature from the perspective of the shari $\hat{i}^{\prime} a b$. Rather, these theories focused on the political processes, so as to examine whether or not they conformed to sharî $\hat{i}^{\mathrm{b}} \mathrm{h}$ principles. The symbiosis of religion and politics, in this respect, did not exist at a conceptual level, but at a more practical one, because the pre-modern thinkers were not faced with a "secularistic ideology", but rather, with a "secularistic mode of life" appearing in the form of materialistic and hedonistic tendencies among the political elite.

The pre-modern Islamic political paradigm thus emerged with a double role, namely to justify the political reality on the one hand, and to provide that political reality with moral duties on the other. The first position became the stress of the juristic tendency, and the second was the main purpose of the administrative bureaucratic and the philosophic tendencies. Both positions were meant to assert the 
supremacy of religion over politics. As a result, the symbiosis between religion and politics in the pre-modern paradigm appeared to clarify the function of each in their mutual relationship.

However, pre-modern Islamic political thought is not uniformly articulated. Al-Mawardî (d. 1058), for example, emphasized the prophetic mission of the caliphatic political institution as including both religious and temporal purposes - suggesting a reciprocity between religion and politics, i.e, that religion affirmed the "religious" nature of this political institution, which functioned to protect the religion itself. Al-Ghazâlî (d. 1111) chose to assert the twin-brotherhood of religion and politics and its divine nature -implied juxtaposition of the two. Since al-Mawardî and al-Gazâlî responded to the political realities from the point of view of religion, their solutions in fact aimed at "religionizing" politics. If that is the case, then the mutual relationship in the symbiosis can be described as religion guiding politics which, in turn, benefits religion itself. Al-Farâbî (d. 950) went even further in his analysis of the nature of the symbiosis. Based on his concept of the ideal society, he held that religion determines an ideal form of political institution, and that this was, at the same time, the ultimate goal of religion itself.

The pre-modern political thinkers, despite their diverse inclinations in their attempts to harmonize the religious and political realities, seem to have reached an agreement that religion and politics in Islam are symbiotically related. Both the caliphate and the ideal society symbolized the symbiosis between religion and politics, or, in other words, they were, in fact, political regimes but with religious ends.

The modern paradigm of Islamic political thought offers another kind of symbiotic relationship between religion and politics. Unlike the pre-modern paradigm which subordinated politics to religion, the modern paradigm subordinates religion to politics. In this context, the modern Muslim political thinkers tend, in their responses to modern political ideas and institutions, to make religion a means of legitimation for the sake of reconciling religious ideals and the political realm. This legitimation takes the form of a return to an autochthonous Islamic political and cultural inspiration, either in the form of revealing a traditional political institution and retrieving an Islamic alternative, or in the form of seeking compatibility between an Islamic institution and modern institutions. 
However, the modern thinkers' subordination of religion to politics does not mean that they neglect the sharíab. The modern paradigms maintain a strong allegiance to scripturalism, but this allegiance is meant to be a search for a "refuge" from the peril, as they perceive it, of Westernization. In this case, the modern thinkers' allegiance to scripturalism, particularly that of traditionalists, did not lead them to exercise a real ijtibâd by elaborating on Islamic injunctions from scripture in order to encounter the incoming cultural force, because they in fact avoided the encounter and thus escaped the problem. Muslim political thinkers in the modern period, such as Rashîd Ridâ and Sayyid Qutb may well have intended to solve the problem, yet it remains unsolved. This problem, stemming primarily from the inevitable dialogue between Islam and modernity, lies in the question of how to develop Islamic authenticity in the process of modernization.

The modernists also not succeed in solving the problem because of their partial treatment of both Islamic authenticity and modernity. In their leaning towards modernity, they are trapped in a superficial level of meaning, resulting in the adaptation of modernity's outer form without actually adopting its inner dynamic for progress and development. The modernists' inclination toward scripturalism also does not lead them to its esoteric dimension of significance, and therefore they fail to find scripturalism's potential morality for the development of human civilization. The rationalization of Muhammad 'Abduh (d. 1905), the secularization of 'Ali ibn 'Abd alRâziq (d.1966), and the speculative reconstruction of Muhammad Iqbal (d. 1938) did echo appeals to cultural reform and liberalism, but these were not followed by a systematic blueprint of modernization.

If the pre-modern paradigm of Islamic political thought tended to "religionize politics", the modern paradigm tended to politicize religion. The politicization of Islam, in this case, took the form of the creation, in the name of Islam, of political ideas and institutions to justify the ongoing political processes. This attempt thus far failed to achieve significant results in bringing Muslim culture to a level of superiority in the course of its acculturation with both Western and indigenous cultures. The main problem of the modern paradigm lay in its "inferiority complex" in the face of Western culture, and this leads to the emergence of two extremist attitudes toward the West: 
positivism on the part of Islamic modernism and negativism on the part of both Islamic conservatism and Islamic fundamentalism. Both attitudes reveal the crisis in which modern Islam has found itself and suggest that the problem involving Islam and modernity has remain unsolved. In the political domain, this means that the modern paradigm of Islamic political thought has not yet brought about a satisfactory reconciliation between Islamic ideals and the political realm. How about modern Islamic political thought in Indonesia?

\section{Indonesian Political Islam: A Socio-cultural Setting}

Indonesian political Islam is not a single phenomenon, it consists of heterogeneous features. This heterogeneity embodies at least three dimensions. The first is cultural, that is, the various Muslim groups in Indonesia have distinct religio-cultural backgrounds which correspond to their socio-cultural backgrounds. Pluralism in Indonesian society, with its Muslim majority, is based on common ethnic backgrounds, languages and customs, but has also been strongly influenced by geography; by the power of nature over culture. The affinity of the socio-cultural dimension with the religio-cultural Indonesian may be explained by the fact that, at the practical level, religion is an aspect of culture. The transformation of cultural behavior into religious cultural behavior goes through the process of religious perception.

The second factor is psychological. This cultural sentiment and tension developed a certain psychological distance among Muslim groups. A religious theory originating in one group would be explored and challenged in dialectical interaction by other theories originating in other groups. There was constant debate, and in offensive-defensive interaction, new theories were brought forward to support the paradigm of one or another particular group. Thus, every new religious idea had a functional dimension : it was a tool to justify the cultural solidarity of its originaters.

The third factor is political. This developed out of two previous factors. Each group engaged in political competition in order to demonstrate its cultural identity and to disseminate its own religious views. The political history of Islam in the Old Order Indonesia included competition between various Islamic political parties, each competing with the others in promoting its own "ideology" in order to gain political support from the ummat Islam for its own sectarian goals. 
Indonesian political Islam has faced a dilemma stemming from several factors. The first is overestimation of the strength of political Islam. Muslim political leaders have often proudly referred to Indonesia as ninety per cent Muslim, basing on this claim, their optimism regarding gaining political power. Yet such overestimation and optimism is far from reality. In fact, less than 50 per cent of voters supported the Islamic parties in the national election of 1955; and only $27.11 \%, 29.29 \%, 27.78 \%$, and $18.8 \%$ of voters supported the PPP (a party with Muslim social origins) in 1971, 1977, 1982 and 1987 respectively. Compared to the number of Muslim voters in each general election, these statistics also show that a great number of Muslim voters did not support formalistic political Islam (read: Islamic parties/PPP), as found in 1955 (50.5\%), 1971 (31.1\%), 1977 (30.6\%), $1982(31.3 \%)$ and $1987(18.0 \%) .^{3}$

The second factor is what may be called an "ambivalent definition" of the ummat Islam (Muslim community). Although many Muslim leaders claim that the followers of Islam constitute about 90 per cent of the total population, their use of the term ummat Islam is incorrect and misapplied. This in turn has misled many observers of Indonesian politics, since they perceive Muslims to be the supporters of political Islam. Muslim leaders use the term ummat Islam, as many observers do, to refer to those who are formally members and supporters of an Islamic political party, or of any social organizations with Islamic symbols and names. By so doing, they exclude a large number of those who confess Islamic belief and do not want to be called non-Muslims. ${ }^{4}$

The third factor is that there has not yet been a development of thought among Muslim political leaders and thinkers regarding the appropriate relationship between Islam and politics. It can be said that all Muslim leaders view the two as being inseparable, or that politics is included in Islam. Also, concerning the kind of political system to be adopted, in general, as Ahmad Syafii Maarif concluded, ${ }^{5}$ Indonesian Muslims leaders had, from the very beginning, chosen a democratic political system. In their view, democracy is a political mechanism whose use is most relevant to the achievement of the Islamic political ideal.

Yet, the question of how Islam is to be implemented in day-to-day politics and in order to achieve the Islamic political ideal, or, in Allan Samson's terms, how Islamic belief is to be realized in political action, has received no single answer. 


\section{The Tendencies of Indonesian Islamic Thought}

Islamic intellectualism in Indonesia in the last few decades has represented a variety of ideas, yet they have a common purpose, of reformulating Islamic answers to the social problems faced by the Muslim community. These ideas resulted from two coincidental factors, the real condition of the Muslim community stemming from its struggle in seeking an appropriate relationship between Islam and Indonesian culture, and the emergence of a new educated Muslim generation. This generation is the product of some four decades of history since Indonesia's independence. The leaders of this generation are concerned about the condition of the Muslim community and are dissatisfied with the ways the older generation has attempted to overcome problems.

In general, Islamic thought in modern Indonesia may be categorized, in terms of emphasis, into three tendencies. ${ }^{6}$ The first tendency maintains the necessity for a new theology to be adopted by Indonesian Muslims in seeking an appropriate relationship between the Islamic world view (wawasan keislaman) and the Indonesian world view (wawasan kebangsaan). This tendency is composed of two schools of thought. One consists of the indigenists, i.e., those who maintain that Islam is a universal religion but that its implementation should be culturally specific.

The pioneers of this school are inclined to suggest that Islamization in Indonesia should not contradict the process of Indonesianization, as Islam, according to them, is complementary to the Indonesian world view. Indigenist thinkers view Pancasila as being similar to the Medinah Charter and at most is an expression of Islam as relevant to Indonesia.?

The other school consists of the universalists. The pioneers of this school assert that Islam is a universal religion based on the principle of unity (tawhidd). From their point of view, Islam has, from the beginning, had a revolutionary character which enables Muslims to take part in social change. ${ }^{8}$ According to the universalists there are some fundamental values that should be applied by Muslims in order to establish a state or a society: justice, including equality of opportunity and equality of results; and consultation (shîrâ), which is the essence of democracy.

The second tendency considers that the main problem faced by Indonesian Muslims is in the political field, in particular concerning the question of what the proper relationship between Islamic belief 
and political actions should be. Intellectuals of this tendency are concerned with the fact that Muslims, regardless of their demographic potential, occupy only a marginal position in the national political arena. In their observation, the situation derived from Muslims' ineffective role in playing politics is due to some internal problems, a long side the fact that the regime exercised some political engineering.

The pioneer of this tendency suggest a political mode of problem solving. In the intellectual domain, problem solving initiates politi$\mathrm{cal}$ ideas that seek the appropriate place and role of Muslim groups in Indonesian political history and in the national development of the nation.

The third tendency holds that the main problems of Muslims in Indonesia lie in the areas of economy and education. The pioneers of this tendency are mostly involved in community development activities through the various non-governmental organizations (NGOs) that they have established. The involvement of Muslim activists in NGOs is remarkable. The wide range of activities of these NGOs in community development has had a great impact on the development of the Muslim community, particularly in rural areas.

\section{The Mainstreams of Indonesian Political Thought}

Despite the weaknesses of categorizational analysis in explaining the nature of the reality, ${ }^{9}$ categorization is inevitable if one is to analyze a complex phenomenon, such as Islamic movements and thought in a predominantly Muslim country like Indonesia. Analytical categories will not only help to distinguish the viable tendencies involved in the manifold phenomena of Islamic movements and thought - forming diverse types of responses to the external challenge, namely the West-, but will also help to clarify the degree of influence exerted by similar movements and ideas maintaining the continuity of the Islamic social and religious heritage.

As far as political thought is concerned it is observable that there have been at least three mainstreams of thinking among Indonesian Muslim intellectuals. These mainstreams are the outcome of "dialectical" interactions among intellectuals and became nuances in the variegated pattern of Islam in modern Indonesia.

The first mainstreams may be called "formalistic". This term is meant to denote the mode of thought of those maintaining the strict 
observance of recognized Islamic forms. Formalism in Islamic thought usually emphasizes the Arabic cultural symbolism which is believed to be prestine Islam. Stressing the utilization of Arabic cultural terms in non-Arab countries, like Indonesia, indicates the importance of religious formalism. That is to say that the substantive meanings of a term, which may well be conveyed in other languages, do not seem more important than their forms. The emphasis here lies in the real effect of the terms, rather than the epistemological sense of comprehension. This tendency shows a lack of creativity in developing sociocultural terms in the language of the specific culture, which, in substance, convey the essence of Islamic teachings. The formalists' preservation of the linguistic authenticity of the revelation not only reveals their strong attachment to scripturalism, but also shows their tendency to take a literal or textual approach to it.

Some elements of Islamic formalism are viable, in for example the ideas of universalist intellectuals. ${ }^{10}$ Islamic universalism upholds both the universal and the totalitarian nature of Islam. Universalist thinkers tend to emphasize Godly authority in the principle of unity (tawhîd $)$, which in their view serves to liberate human beings from non-Godly authorities. The universalist thinkers share the idea of Islamic fundamentalism, particularly regarding to the phenomena of "Westoxication," to borrow Amien Rais' term, or Saefuddin's "modern jâhilî society. "In order to make Islam a liberating force, the universalists see the necessity of an institutionalized Islam. As Saefuddin has stated, this institutionalization would pave the way for the emergence of a "Qur'ânic modern society, that is, a society which is capable of guarding itself from the overflowing cultural trends transforming universal culture" ${ }^{11}$

The necessary of emphasizing the existence of Islamic institutions as the formal agencies to carry out Islamic principles characterizes Islamic formalism. In the political sphere this mainstream proposes an Islamic form of a political institution. Therefore it is opposed to a mainstream which tends to stress the importance of a substantial level of meaning while denouncing formalistic modes of thought. This mainstream can, thus, be labelled "substantivistic."

This term is meant to signify the political orientation of those emphasizing that there must be substantial manifestations of Islamic values in political activities, not merely their formal appearance, either in types of political ideas or in institutions. To the proponents 
of this orientation, the intrinsic existence of Islamic injunctions in the Indonesian political scene is more important, and is sufficiently adequate to promote Islamization in the face of culturalization towards a modern Indonesian society.

This serves as one basic argument for the substantivists, that in the historical perspective, this culturalization has included competition between various cultural forces and Islam is just one of them. In order for Islam to be victorious in this competition, Islamization, the substantivists say, must take the form of culturalization, not politicization; Islamic movements should become cultural movements, rather than political movements.

The idea of emphasizing a cultural mode of Islamization has been advocated by the so-called indigenist thinkers, ${ }^{12}$ who have sought to adjust Islamic ideals to Indonesian national culture, and who make a clear distinction between Islam and the state. One pioneer of indigenism was Abdurrahman Wahid, who initiated the idea of the "domestication" of Islam (pribumisasi Islam) in the face of Indonesian culture. The idea was based on a postulate of the pluralism of Indonesian society, in which Islam serves as merely one complementary factor. In this connection, it is important for Muslims to develop a national consciousness (kesadaran kebangsaan). Because, as Wahid viewed it, it was on the basis of this consciousness that the Indonesian state was established..$^{13}$

Wahid's socio-historical argument makes a consequential plea for the de-ideologization of Islam. In the Indonesian context, this idea has shown a dialectical dynamic, to borrow Ali and Effendy's term, in overcoming the conceptual problem concerning the relationship between an Islamic worldview (wawasan keislaman) and an Indonesian worldview (wawasan keindonesiaan), and has contributed to seeking a place for Islam within the framework of the Pancasila state.

Likewise, this is the case with Nurcholish Madjid's ideas. His proposal "Islam-Yes, Islamic Party-No" and his view of Islam as a complementary factor served not as a point of departure, but rather as a concluding remark derived from his reflections on Islam and Mus$\lim$ historicity in Indonesia. He finds that, as a religion of fitrab stressing human being's inherent potential in upholding the true and the good-Islam is indeed a universal religion confirming universal humanistic ideals, teaching inclusivism rather than exclusivism. Islam's inclusive nature brought Madjid to suggest an inclusive mode 
of interrelation and interaction to be maintained by Indonesian Muslims in the context of the pluralistic configuration of Indonesia society.

Madjid goes on to maintain that it is imperative to consummate democratization, which he views as a dynamic process adequately enabling a society to draw closer to democracy. This, he states, necessitates a "gentleman's agreement" that transcends religious as well as cultural primordialism. It was on the basis of this idea that Madjid developed his juxtaposition of Pancasila with the Medinah Charter, which, in his view, constitutes a consensus between Muslims and other groups to build a political society for all. Thus, Indonesian Muslims, he said, did not perceive Pancasila and the 1945 Constitution as alternatives to Islam, just as the Prophet Muhammad and his followers did not conceive the Medinah Charter as an alternative to their new religion.

The historical and philosophical justifications of the substantivist thinkers concerning the proper relationship between Islam and the state has led to their substantiation of the existing forms of political institutions. Substantivism, in the Indonesian case, has also manifested itself in a more "praxical" mode among the the NGO's activists such as Dawam Rahardjo or Amin Aziz who chose to emphasize "program actions" over "theoretical propositions." Their substantial level of observation of the problems of the Muslim community has encouraged them to launch community development programs of non-political activities, yet which could have political implications. It is for this reason that these thinkers are included in the substantivistic political mainstream.

Apart from the formalistic and substantivistic mainstreams, which are diametrically opposed to each other, a third mainstream cannot be ignored. This mainstream tends to retrieve and insert Islamic fundamentals into current social and political realities and tries to revive Islamic culture. This mainstream, which may be labelled "fundamentalistic" on the one hand, and "revivalistic" on the other, had, as their point of departure, a conviction that both the other mainstreams had failed to show Islam as a counter-balance in order to provide an Islamic response to Indonesian modernization.

Meanwhile, from the methodological perspective, Muslim fundamentalists and revivalists cannot be said to maintain one of the two approaches to Islam, i.e., formalistic and substantivistic, in a separate 
and strict sense. They tend to combine or choose one of the two approaches in accordance with the subject matter. In the political context it evinces an orientation that has always tended to sustain the pre-conceived forms of Islamic polities, such as the importance of a formal Islamic political party (bearing the name of Islam), the expression of Islamic political idioms and symbolism, and, at the utmost, experimentation with an Islamic constitutional organization.

From the point of view of the Muslim revivalists, a true Islamic culture has to be revived. This aim necessitates cultural transformation into an Islamic one. If the transformation of society means social change, Islam's transformative nature requires a process of change, either revolutionary or evolutionary. The choice between these two options remains uncertain and ambivalent in the fundamentalistic and revivalistic mainstream thinking of Indonesian Muslims.

The emergence of Islamic fundamentalism in Indonesia was influenced in part by an external international factor, that is, the development of fundamentalism in the Muslim world, and by the internal dialectical dynamic within the Muslim community in Indonesia. The social and political inability and ineffectiveness of the established Islamic movements in the face of the regime's national development encouraged the emergence of "Islamic revivalism" in Indonesia. Indeed, Muslim revivalists challenge the Islamic establishment by offering a kind of alternative.

Islamic history in New Order Indonesia has witnessed the coming into being of several Islamic revivalist groups, including the Jamâ'ah Tablîgh (Association of Islamic Preaching), the Jamâ'ah Tanbîh ("Islamic Warning"), the Hizb al-Tahrîr (Party of Liberation), the Shi'ah, and the Usrah (literally "family") circles, who adhere to both the Ikhwân al-Muslimûn (Muslim Brotherhood) in Egypt and the Jamaat Islami (Islam Association) in Pakistan. These groups, have not, in fact, revealed a visible mainstream but are increasing. Yet, what is clear is that they challenge the mainstreams, the established Islam.

The emergence of Islamic fundamentalism in contemporary Indonesia was encouraged by the situational logic of politics, in which Muslims are threatened while Islamic organizations do not take any measures to articulate their political interests. Furthermore, the accommodative ideas of modernist Muslim thinkers are, of course, from the perspective of Muslim fundamentalists, perceived as leading po- 
litical Islam to further defeat. These internal factors are triggered by an external factor, the influence of the Islamic revolution in Iran. This became effective with the publication of influential works by Iranian intellectuals like 'Ali Shari'ati, Mutahhari and Khomaini. The success of that revolution inspired the fundamentalists to dream of it happening in Indonesia, the largest Muslim country.

However, the appeal of Islamic fundamentalism was not so attractive to the majority of Indonesian Muslims. There are three possible reason for this. Firstly, the nature of Indonesian Islam which, following the line of Indonesian culture, is devoted to moderation, tolerance and harmony, would hardly find any kind of radical and fundamental change acceptable. Secondly, the situational logic of politics, which has created fear and to some extent apathy within the society would scarcely encourage Muslim leaders to initiate political change by attempting to seek justifications for Islam. Thirdly, the novel feature of Indonesian national politics that is favorable and conducive to the Islamic cause, also impedes the fundamentalist orientation in religious life.

\section{Discourses on Islam and the State}

Little intellectual response has been shown, such as elaboration on the relationship between Islam and the state, the Pancasila and politics, with the exception of the accommodationist responses of Mintaredja and Nurcholish Madjid. ${ }^{14}$ Mintaredja (then chairman of Parmusi and later of the PPP) in his reflection on Islam and Pancasila, considers that Islam does not aim at the creation of an Islamic state because, "during the time of the Prophet Muhammad...the term 'state' in the sense of state as we know it today, was not yet in existence". ${ }^{15}$ In Mintaredja's view, the duty of Muslims is to struggle to create a true Muslim society, which should be distinguished from an Islamic state. A Muslim society can legitimately exist in a state without undermining its integrity as the nation-state. ${ }^{16}$

Concerning the relationship between Islam and politics, Mintaredja, while believing in the totalistic characteristic of Islam as a way of life, including political life, maintains that political issues are worldly in nature and as such an approach to political issues should be in accordance with this nature. The core of Mintaredja's ideas is that "there is to some extent a separation between State and Church in Islam". ${ }^{17}$ 
Having observed the problematique of Indonesian Islam, which lies in the paradox between the defeat of political Islam and the rapid expansion of Islam, Nurcholish Madjid came to the conclusion that its quantitative growth was not encouraged by Islamic parties or organizations, for these organizations have failed to build a positive and sympathetic image of Islam. ${ }^{18}$

With regard to the relationship between religion and politics, Nurcholish Madjid preferred to separate the two. To him politics, or more precisely the state, is one of the aspects of material life whose dimension is rational and collective, while religion is another kind of life whose dimension is spiritual and personal. Thus, the concept of an Islamic state is a distortion of the appropriate relationship between Islam and the state. According to Madjid the idea of an Islamic state in fact reflects a kind of apologetic attitude on at least two bases, as follows:

"The first was an apology in relation to modern Western ideologies such as democracy, socialism, communism and others... The apology in relation to modern ideologies gave rise to an ideological-political understanding of Islam which then lcd to the ideal of an "Islamic state"... This totalitarian ideological-political apperception led to the emergence of apologetic thinking which declared that Islam was not merely a religion...(but) addin...The apology...was deemed necessary because in modern life, dominated by Western patterns, the most important aspects of life are the political, economic, social and the rest...Thus the apology was compensation for an inferiority complex", 19

Leaving aside polemics among Muslim thinkers about the question of the relationship between Islam and the state which revived the dynamism of Islamic thought in Indonesia at the beginning of the 1970s, Madjid's ideas, and those of Mintaredja, clearly showed an accommodative tendency toward the regime's political policy. These ideas, according to Madjid, constitute "an attempt to reformulate in general terms the fundamental Islamic postulates regarding God, man and the physical world, and the manner of their relationship in the light of new political realities". ${ }^{20}$

Other than this mode of intellectualism, so-called "infra-structural politics" is also emerging. This idea refers to political activities aimed at empowering the people through strengthening their infra-structures. Some have attributed this kind of orientation to NGO activists, such as Abbdurahman Wahid. ${ }^{21}$ 
"Infra-structural politics" is fashionable among Muslim NGO activists who believe that empowerment of the Muslim community can only be achieved through community development. In their view, this process will lead to the development of a civil society in Indonesia.

Meanwhile there are those who try to broaden the political leverage of Islam through structural pathways. Among its ardent supporters are ICMI activists, Muslim politicians and bureaucrats. In their opinion, Islam has to maintain relative proximity with, instead of hostility towards the state. This is to ensure the political participation of Muslims in the decision making process.

\section{Concluding Remarks}

The reconciliation between Islamic ideals and political realities became more difficult when Islam faced an indigenous culture and politics, which also faced the same challenge: the challenge of modernity. The implementation of Islamic ideals into political realities, in this context, faces the problem of strategic accommodation, that is the problem of how to accommodate modernity and indigenism.

Acculturation between Islam and the indigenous political culture and also modernist culture has been taking place through a reciprocal mode of interaction producing a harmonious relationship between the regime and the ummat Islam. It is this relationship that has encouraged the emergence of an Islamic cultural revival.

The harmonious relationship between the regime and the ummat Islam is the result of the transformation of political ideas and practices among Muslim political thinkers and activists. ${ }^{22}$ According to Bahtiar Effendy, this transformation is the result of an integrative approach towards political realities by Muslim intellectuals, who responded with three different modes of intellectualism: theologi$\mathrm{cal} /$ religious renewal, political/bureaucratic reform, and social transformation. ${ }^{23}$

It is obvious that the drive towards Islamic cultural revival was not indebted to the politicization of Islam, in its strictest sense, i.e., the pursuit of practical politics, but rather, to a viable dynamic yet harmonic atmosphere within the Muslim community at large. This state of affairs resulted from the process of the Muslims' self-resignation, a process which, in turn, led them to exercise another type of struggle and interaction with the authority. Instead of striving to 
political Islam, again in the sense of playing practical politics, the Muslim groups launched a campaign of "cultural absorption into Islam".

As a result, there emerge three kinds of religious consciousness among Indonesian Muslims. The "lower class" - who have not shared the advantages of modernization, because this has only, for them, broadened the social and economic gap between the haves and the have-nots - reacted by returning to Islam. The common people expressed their religious consciousness through their active attendance at various religious gatherings, while others, particularly Muslim students, attempted to seek an Islamic response to social problems. The "middle class", the petit bourgeoisie, who have lived a material life, felt it necessary to clothe themselves with a religious life on both the individual and the social levels.

The increase of religious consciousness among Indonesian Muslims could usher in a new dimension of Islamic polity in Indonesia which could lead to the development of a civil society. This is only possible if Muslim groups, the majority of the Indonesian people, maintain their commitment to democracy, social justice, and peace. 


\section{Endnotes}

1. The terms are borrowed from Bassam Tibbi, who tended to view the mode of response of "the inferior" towards "the superior" as including three phases: cultural revitalization, self-resignation and projection, and cultural retrospection. See Bassam Tibi, The Crisis of Modern Islam (Salt Lake City: 1988) pp. $12-$ 12.

2. Islamic political thought corresponds to either the Laswellian type of politics, that is "who gets what, when and how", or the Eastonian type: "allocation of authoritative values within a society as a whole and for a whole". See Harold D. Laswell, Politics: Who Gets What, When and How (New York: 1936), and David Easton, "An Approach to the Analysis of Political system" in World Politics, IX (1957).

3. Modified from Biro Pusat Statistik, (Jakarta: 1984); Herbert Feith, The Election of 1955 (Ithaca: 1971); Mahrus Irsyam, Ulama dan Politik, (Jakarta: 1984); Abdul Munir Mulkhan, Perubaban Perilaku Politik dan Polarisasi Ummat Islam 1965-1987 (Jakarta: 1989).

4. For a more detailed description of the development of the term ummat in Indonesian Islam, see Sidncy Jones, "The Contraction and Expansion of the "umat" and the rolc of the Nahdlatul Ulama in Indonesia" in Indonesia, $38: 1$ 20 .

5. Ahmad Syafii Maarif, Islam dan Masalab Kenegaraan: Studi tentang Percaturan dalam Konstituante, (Jakarta: 1987), p. 125.

6. The best work to date that attempts to reconstruct Islamic thought in modern Indonesia is Fachry Ali and Bahtiar Effendy's Merambah Jalan Baru Islam (Jakarta: 1986). See also, R. William Liddle, "Politics and Culture in Indonesia", unpublished research paper, pp. 34.

7. Ibid., pp. 82 .

8. Ibid., pp. 255.

9. According to Prof. Binder, this was due to the fact that "most of these classificatory schemes are used for the sake of convenience, and they are never the major topic under investigation. Moreover, each scheme is elaborated without reference to other parallel efforts, and is often closely related to the specific problem the researcher has in mind". Similarly, William E. Shepard has said that these labels, and the label "fundamentalist" in particular, of ten serve as obstacles in understanding the reality of Muslim life, in part because they are frequently used without explicit definition, in part because they often convey an implicit bias or value judgment.

10. In an attempt to map the modern development of Islamic thought in Indonesia, William Liddle has included this mainstream in his trichotomy (the other two belong to the indegenists and NGO reformists respectively). This trichotomy is similar to Fachry Ali and Bahtiar Effendy's quadrichotomy, i.e., Neo-modernism, Socialism-Islamic Democracy, Internationalism and Universalism, and Islamic modernism. Both include in the universalist group, Amien Rais, now the Chairman of Muhammadiyah who teaches at Gajah Mada University in Yogyakarta. In addition, for Ali and Effendy, Jalaluddin Rahmat, a prominent Muslim intellectual teaching at Pajajaran University in Bandung and Ahmad M. Saefuddin, another active intellectual of the Bogor Agricultural Institute. However, this inclusion should not to be taken in an absolute sense, since these thinkers put forward transcategoric ideas on some occasions. 
11. A.M. Saefuddin and Y. Marasabessy, "Etos Kehidupan Masyarakat Modern", Universitas Ibnu Khaldun, Bogor, n.d. quoted in Ali and Effendy, op, cit., p. 276.

12. The writer tends to concur with Prof. Liddle, and sees the term as more appropriate for characterizing the ideas of those such as Nurcholish Madjid and Abdurrahman Wahid. Sec Liddle, "Politics and Culture", op. cit., p. 24. Ali and Effendy's attribution of neo-modernism to the two thinkers, due to their inclination to combine Islamic modernism and Islamic traditionalism, is useful. If this is the case, howcver, the category should thus be made in accordance with the emphasis on the combination.

13. Ali and Effendy, op, cit., p. 191-192.

14. Among other types of Muslims' responses to the New Order modernization, the two responses to political change were intellectual in nature and deserve to be discussed, since they have been published in formulation. See Muhammad Kamal Hassan, Muslim Intellectual Responses to "New Order" Modernization (Kuala Lumpur: 1980), pp. 78-116.

15. H. M. S. Mintaredja, Renungan Pembaharuan Pemikiran: Masyarakat Islam dan Politik di Indonesia, (Jakarta: 1971), pp. 77; Muhammad Kamal Hassan, Muslim Intellectual, op. cit., pp. 88.

16. Mintaherdja, Renungan, op. cit., pp. 88.

17. Mintaredja, Renungan, op. cit., pp. 83; Muhammad Kamal Hassan, Muslim Intel lectual, op. cit., pp. 88.

18. Nurcholish Madjid, "Keharusan Pembaharuan Pemikiran Islam dan Masalah Integrasi Ummat" in Pembahuruan Pemikiran Islam (Jakarta: 1970) pp.1-12.

19. Nurcholish Madjid, "Menyegarkan Faham Keagamaan di Kalangan Ummat Islam Indonesia"; English translation cited from Muhammad Kamal Hassan, Muslim Intellectual, op. cit., p. 231.

20. Muhammad Kamal Hassan, Muslim Intellecttual, op. cit., pp. 89.

21. For recent accounts, see discussions by Arief Afandi, Arief Budiman, Eros Djarot, Kuntowijoyo, and Fachry Ali in Jawa Pos, May, 11-17, 1995.

22. A comprehensive and analytical discussion of this transformation has been undertaken by Bahtiar Effendy. See Bahtiar Effendy, "Islam and the State: the Transformation of Islamic Political Ideas and Practices in Indonesia" (Ph.D dissertation, Ohio State University, 1994).

23. Ibid., pp. 1-2.

M. Din Syamsuddin is the Director of the Central for Policy and Development Studies (CPDS), Jakarta. 